\title{
Payment For Environmental Service: An Application in Tourism in Vietnam
}

\author{
Nguyen Van Hieu ${ }^{*}$, Dang Thi Thanh Thuy ${ }^{2}$, Nguyen Hoang Nam $^{3}$ \\ ${ }^{1,2}$ Capacity Development Center for Environment and Natural Resources (CEN), Hanoi, Vietnam \\ ${ }^{3}$ National Economics University (NEU), Hanoi, Vietnam \\ * E-mail: hieunguyen@cen.org.vn
}

\begin{abstract}
Payment for Environment/Ecosystem Services (PES) is a market-based approach toward the dual goal of poverty alleviation and forest conservation. In Vietnam, PES has been nationwide applied to the forest environment, namely Payment for Forest Environmental Services (PFES). Nevertheless, the PFES application in forest-based tourism is very limited. To enhance policy implementation in practice, this study analyses a case study in Sapa town, Vietnam. We find that the overlapping revenue of service providers is a substantial issue holding back PFES applications in tourism. Accordingly, we recommend two potential payers for tourism-PFES, including accommodation companies and ticketing companies (based on the revenue from entrance tickets). We then suggest a PFES payment level of 1 percent of total revenue from ticket sales and room charges. Moreover, the study also provides some recommendations to ensure the fairness and transparency in PES application, as well as factual, reflect of the nature of PFES during implementation.
\end{abstract}

Keywords: Payment for forest environmental services, tourism, payment for ecosystem services (PES)

\section{Introduction}

Starting in the 1990s, payment for ecosystem services or payment for environmental services (PES) has become a popular policy tool for managing natural resources in more than 60 countries [1], [2], [3]. Internationally, PES has been applied in four ecosystem services: biodiversity conservation, watershed services, carbon sequestration, and landscape beauty [4], [5]. Hundreds of PES programs have been implemented worldwide with combined annual payments of over USD 36 billion [3], [6].

PES programs follow a similar payment approach in terms of beneficiaries, payment methods, and mechanisms [7], [8]. Accordingly, existing PES programs only focus on three main ecosystem services: water, biodiversity, and carbon [9]. PES in tourism encompasses a wide range of services, including wildlife and wildlife conservation for consumption (hunting) or non-consumption (sightseeing) and landscape beauty. So far, governments have provided landscape services through conservation areas or cultural heritages. Currently, paying for landscapes often coincides with biodiversity. However, tourists often pay for the landscapes but not for the biodiversity itself.

There are main categories of PES mechanism, including (1) Direct payment - based on a voluntary agreement between the ES receivers and the ES suppliers. In Costa Rica, the Desarrollos Hoteleros Guanacaste hotel pays USD 45/ha/year for 925ha of Acuifero de Guanacaste basin to protect forests to maintain water supply for the hotel [7]. The Profa for carbon PES in Ecuador [10], the Vittel watershed scheme in France [11] and the Simanjiro wildlife conservation scheme in Tanzania [12] are such examples of private PES; (2) Indirect payment - the ES receivers pays to ES suppliers through third parties (e.g. government agency). The Sloping Land Conversion Program in China [13], the Conservation Reserve Program in the USA [14], the PES national 
program in Costa Rica [7], and the Payments for Hydrological Services Program in Mexico [15] are prominent examples; and (3) other payment - organized based on Emission Trading Mechanism (ETM), Clean Development Mechanism (CDM), and Joint Implementation Mechanism (JIM).

In some countries, PES is often implemented in tourism by international organizations or voluntary companies. This payment is often based on site-specific negotiations or entrance fees. In the PES mechanism, tourism-related PES receivers are often households/communities/landowners. They are paid for the management and protection of landscapes and natural resources that are valuable for tourism. Payers are often tourists, hunters, anglers, commercial tour operators, conservation NGOs. In Cambodia, for example, there is currently no clear policy framework on PES. In the field of tourism, PES programs are currently being implemented with the support of small-scale conservation organizations [16], [17]. One of the examples of PES implementation from tourism is the conservation project of endangered birds at the Thmat Boey ecotourism site in Preah Viget province with the support of Sam Veasna Center and the Wildlife Conservation Society. Accordingly, tourists are required to pay more if they see the white shouldered ibis or giant ibis - two bird species are seriously threatened and are the reason for attracting tourists from the world to visit the Thmat Boey community. Community members are paid when they discover bird nests and take care of them [18]. In Tanzania, a group of five travel operators entered into a PES agreement with villagers in Terrat. Accordingly, tour operators will pay villagers around USD 4,500 annually for abandoning farming on 9,300 hectares of land to conserve wildlife and to prevent the construction of permanent settlements [19]. Usually, in public projects, the State (or local Governments, or NGOs) acts on behalf of ESs buyers through general budgets (taxes, fees, grants from international institutions, or ad hoc donations) paying providers directly for agreedupon services [20].

In Vietnam, PES has been applied in the only forestry sector, namely payment for forest environmental services (PFES). In 2004, Vietnam initiated some pilot studies to build the foundation for a national PFES program by the forest ecosystem. Vietnam was the first country in Asia to launch a national program on the PFES scheme under Decision No. 380/QD-TTg in 2008 and the Decree 99/2010/ND-CP in 2010 (Decree 147/2016/ND-CP in 2016, amending and supplementing some articles of the Government's Decree 99) [21]. The PFES policy has been one of the ten greatest successes of the forestry sector in Vietnam during 2010-2020. Accordingly, the PFES policy has been stipulated in the Law on Forestry (2017) and followed by the Decree 156/2018/ND-CP (Decree 156, dated November 16, 2018) on the detail guidance.

Accordingly, one of five environmental services subjected to PFES is "Protection of natural landscape and conservation of biodiversity of eco-systems for tourism services" (Article 61, Law on Forestry 2017). Besides, the Law stated that "organizations, individuals involving in ecotourism business, recreation, leisure must pay a service charge for protecting and maintaining the natural landscape beauty, biodiversity conservation of forest ecosystems". Furthermore, as regulated in Article 59 of Decree 156, the rate of PFES applied to these objects is minimally equal to $1 \%$ of the total revenue gained in the term.

Nevertheless, the practical application of PFES in tourism in Vietnam is considerably limited [22]. It could be due to the variety of stakeholders, types of operations, and complicated supplierbroker-buyer relationship and some specific overlaps of revenues in tourism [21], [23]. This article analyses the issues to recommend an effective implementation of PFES in the practice of tourism. $\mathrm{Sa} \mathrm{Pa}$ town of Lao Cai province is chosen as a case study. 


\section{Methods}

At first, the relevant literature on the institutional structures, performance reports, and other studies associated with PFES schemes was collected and reviewed. The desk study was used to understand the challenges and highlight potential implications for the scaling-up of PFES for achieving the PFES program in tourism driven by the Government of Vietnam to fulfill the social, economic, and environmental objective of forest conservation based on a market-based approach.

After that, the review was followed by expert interviews and focus group discussions. The target audience for interviews and discussion were some leaders, manager, researchers within the Ministry of Agricultural Rural Development (MARD), the Vietnam Forest Protection and Development Fund (VNFF) and the VNFF in Lao Cai province, and also tourism businesses and tourists to understand how the policies have come into effects in practical. Among 44 provinces with PFES applied, Lao Cai is a pioneer province with the most types of environmental services to be paid.

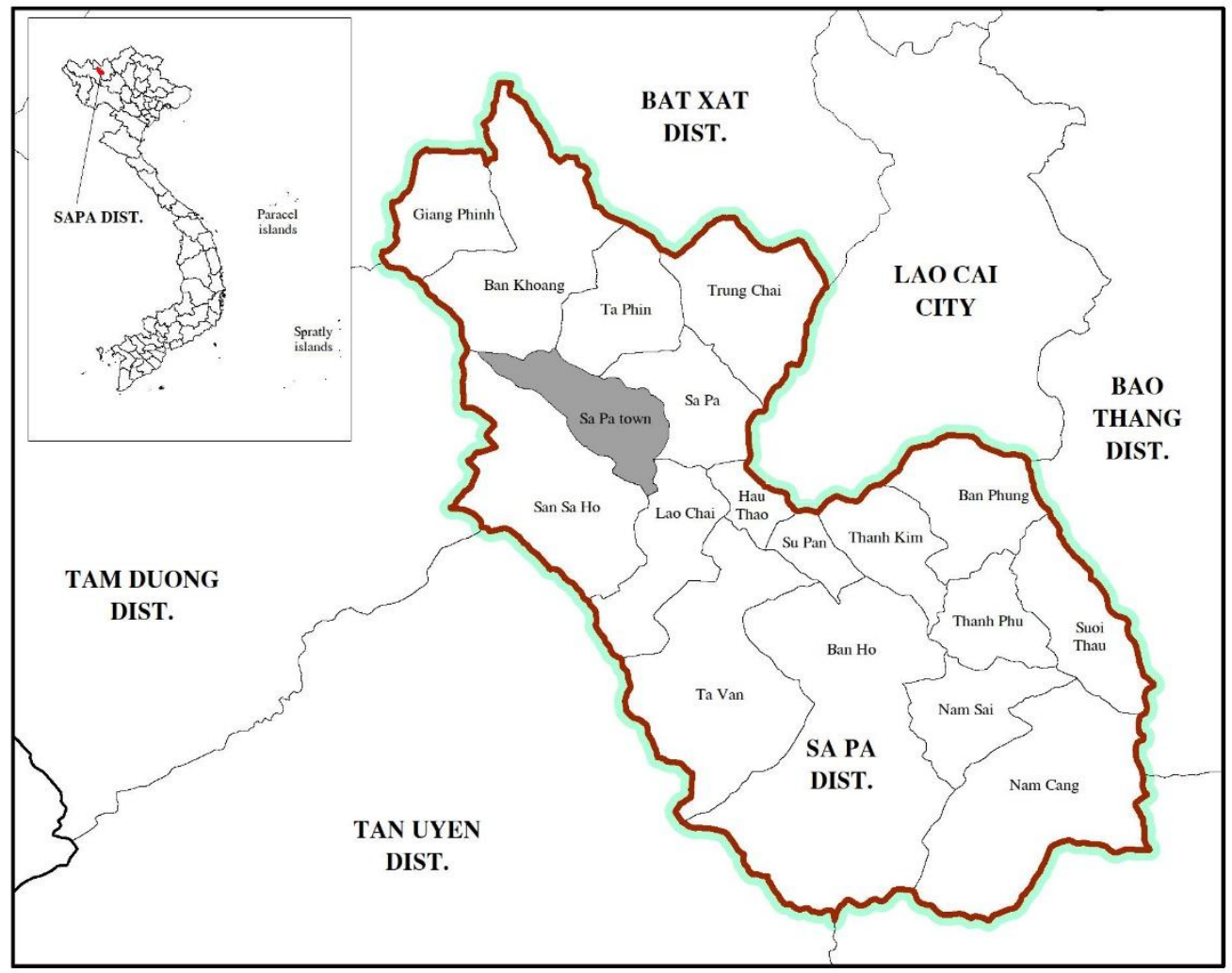

Figure 1

Map of the case study site - Sa Pa town, Sa Pa district, Lao Cai Province

Also, we conducted some fieldwork in Sa Pa town (Sa Pa district, Lao Cai), one of the most popular tourist destinations in Vietnam. Sa Pa district is located within the boundary of Hoang Lien Son National Park, and potential for the implementation of PFES in tourism with the number of tourists to $\mathrm{Sa} \mathrm{Pa}$ in 2019 in 2,968,000 people [24]. Specifically, the study conducted interviews and discussions with 24 tourism companies (02 travel agencies, 04 ticket companies, and 18 accommodation service companies) about PFES policy. 


\section{Results and Discussion}

\subsection{Participating stakeholders in PFES in tourism}

According to the Food and Agriculture Organization - FAO (2003), forests provide landscape values including the natural landscape of rivers, streams, waterfalls, etc. and recreation values for humans such as air quality, recreation spaces, etc. [25]. Without these values, a large number of tourist activities might not be available or be received significantly less income. Specifically, ecotourism and convalescence tourism are particular examples. Therefore, forest protection to maintain these values is crucial to ensure the sustainable development of tourism. In line with the "Beneficial Pay Principle" service users must pay for PFES providers, creating a closed cycle of sustainable natural resource usage. PFES system in Vietnam is shown in Figure 2.

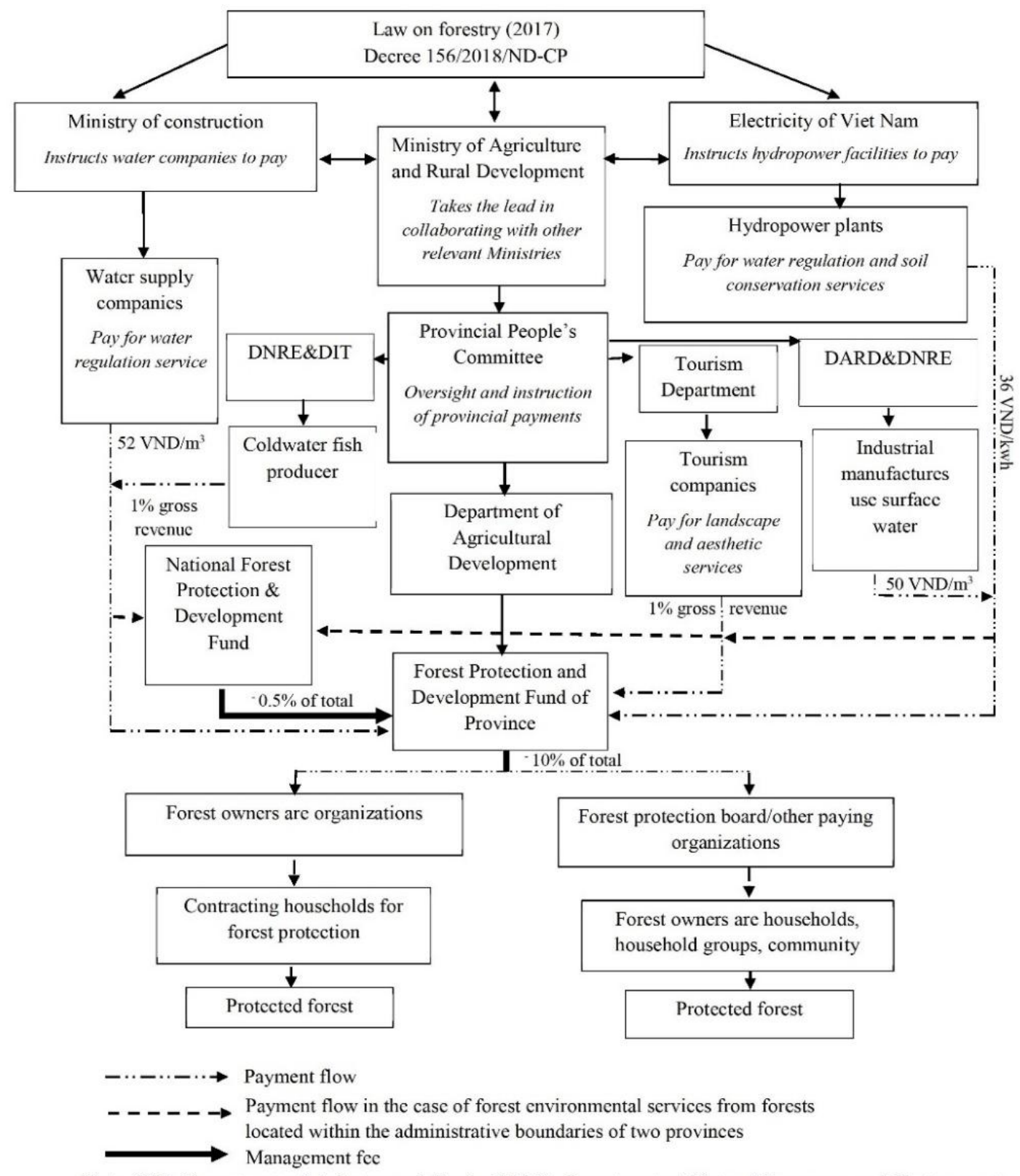

Note: DIT: Department of Industry and Trade; DNRE: Department of Natural Resources and Environment; DARD: Department of Agriculture and Rural Development

Figure 2

Vietnam PFES system

Source: Adapted from De Groot K (2011) [26] 
In practice, stakeholders of PFES in tourism include tourists, tourism companies, national parks and conservation areas, accommodation and transportation providers (PFES-payers and beneficiaries), and the community, national parks, forest protection households (PFES-receivers and suppliers) (Figure 3).

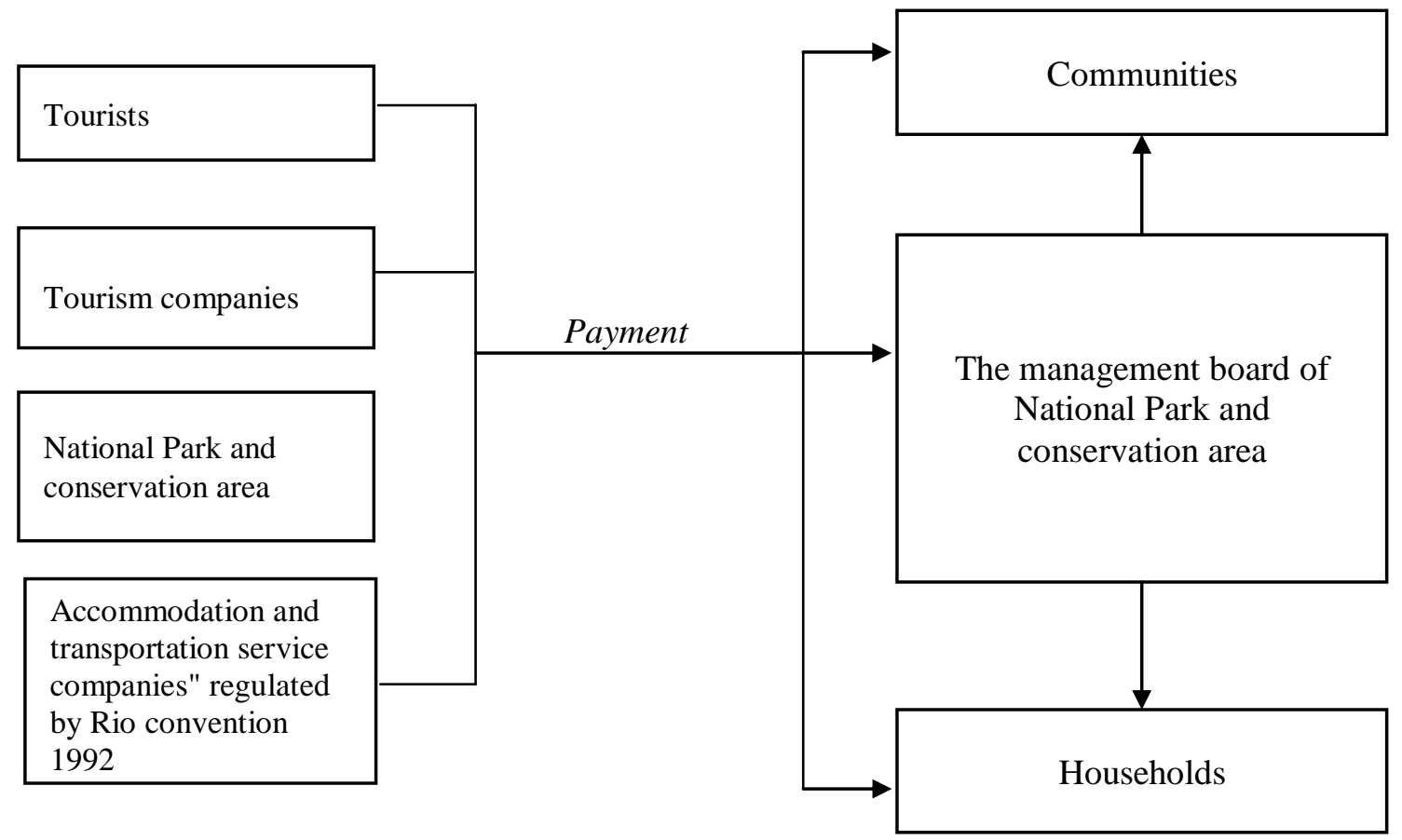

Figure 3

PFES mechanism in tourism

PFES-payers and beneficiaries are those who benefit from the forests. Thus, the payers include: (1) Tourists participating in forest-based tourism activities: enjoying the value of the landscape and recreation; (2) Tourism companies conduct tours to the forest and near-forest tourist sites: benefit from forest-based tourism business; (3) National Parks and conservation area: benefit from tourism business and ticket sales; (4) Accommodation and transportation companies: benefit from accommodation and transportation business in the forest; (5) Households providing homestay service: Benefit from rental and food serving.

However, as regulated by Law on Forestry, PFES-payers include organizations, individuals involving in ecotourism business, recreation, leisure. The business is divided into different services of tourism supplying services such as tourist transportation, accommodation and lodging, catering, shopping service, sport, recreation, leisure, health care, tours, advertisement and other related services serving the tourists within the forests' boundaries where provide forest environmental services to forest owners (Article 57, Decree 156).

According to Decree 156, tourists are not the compulsory subjects who have to pay for PFES while they are the direct beneficiaries of forest environmental services. This is a relevant measure because the law allows accounting expenditures based on the rule of elasticity of the demand curve and the service price will increase. Thus, tourists will have to pay for forest environmental services indirectly through the tourism service cost. This means that all beneficiaries have to pay for FES by different manners.

However, the application of PFES for all objects as Decree 156 in has exposed some limitations and easily leads to the duplication. If PFES collection is based on the revenues from accommodation service suppliers, ticket offices, and travel agencies it would result in the 
duplication of PFES collection from the ticket and room. The reason is the majority of tour operators cover their tour prices of fares and room rates. Figure 4 shows that if PFES collection is based on the revenue of the above companies, the tickets and accommodation will be charged twice. Similarly, the accommodation suppliers have to pay PFES for clean water $\left(52 \mathrm{VND} / \mathrm{m}^{3}\right)$, then the PFES collection for tourism is based on revenue, meaning that they have to pay twice for clean water.

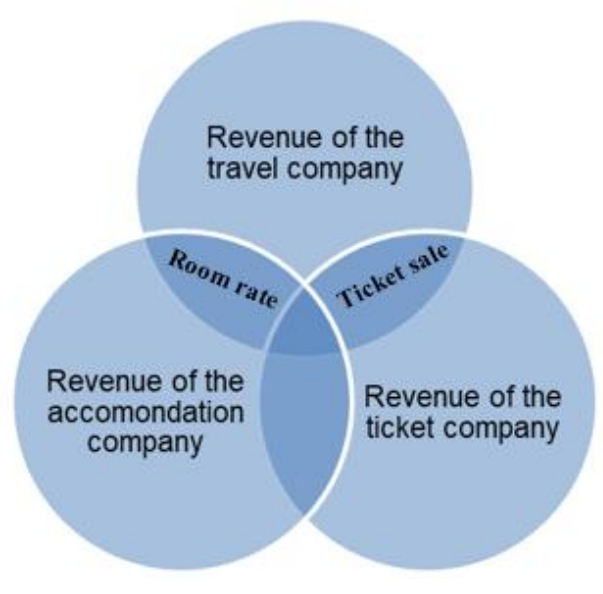

Figure 4

The overlap of revenues between stakeholders

Furthermore, the quality of other tourism services more depends on the supplying quality of restaurants, chefs or the quality of transportation, drivers, etc. and less depends on the forest services whether forests are well protected or not. The application of PFES to the catering, transportation services, and other remaining services may be an example of the improper collection of forest beneficiaries.

To avoid the duplication and to make sure PFES is paid basing on the benefits that the subjects obtained from the forests, we recommended applying PFES for two beneficiaries, including tourist ticket companies (provide tickets at tourist attractions) and accommodation supplying service companies. Accordingly, we also suggested that the implementation plans should be adopted for revenue from entrance tickets and room prices.

Besides, if the basis of payment is the profits from the sale, the nature of the PFES would be ensured, that is the level of payment determined based on the benefits that have been. Meanwhile, the basis of payment based on the number of visitors does not reflect the nature of PFES. For example, a low-end hotel with lower revenues would have to pay the same price as a high-end hotel, with much bigger sales in case such hotels had the same number of arrivals. Thus, the payment rate is not determined based on the benefits. Moreover, such a payment base would create relative difficulties for small companies, serving commoner tourists. This could widen the wealth gap amongst accommodation companies.

During the survey with the participation of 24 tourism companies in $\mathrm{Sa} \mathrm{Pa}$ town (Sa Pa district, Lao Cai province), $70 \%$ of accommodation service companies agreed that the best basis of PFES is revenue from room prices, while $10 \%$ of respondents indicated that the payment should be based on the number of tourists and $20 \%$ agreed with both opinions. Common answers of this group of $20 \%$ are both above bases have advantages and disadvantages, and they will agree to follow the one that is most supported by the majority of the companies. The survey result is presented in Figure 5. 


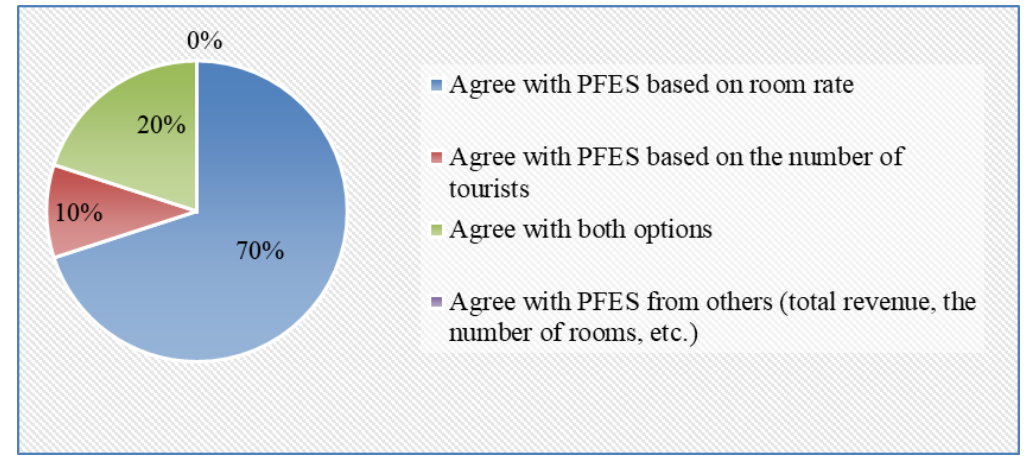

Figure 5

Opinions of accommodation providers on PFES payment basis

Nevertheless, from the survey of this study, we find that: in fact, only 36 businesses agreed to sign PFES-contracts out of 34 travel agencies, 1,248 accommodation service companies, and thousands of entertainment and restaurant businesses in Lao Cai province. One reason could be some small-scale tourist business, such as homestay service which households do not use bookkeeping and receipts, though they have been benefited from forest environmental services. Additionally, their income from the homestay business is not high enough. Furthermore, $85 \%$ of the country's protected areas are located in mountainous and remote areas where the poverty rate is always high [27]. Therefore, a business changing orientation to a type of forest-based tourism for these residents should be encouraged and promoted. This solution might help them to come over poverty and reduce forest exploitation. When the local communities to be aware of the forest value and the benefits of forest protection, they will become the pioneers in forest protection and development. Thus, if they have to pay PFES for their homestay service, this would not be the PFES's initial goal of poverty alleviation. Meanwhile, the big tourist companies are willing to pay PFES for homestay service because PFES cost is not too high for their business. Moreover, these companies also operate with a good accounting system. At the same time, joining PFES also promotes the tourism companies' responsibilities to the local communities and environment.

\subsection{PFES payment rate in tourism}

Clause 6, Article 59 of Decree 156 regulating PFES "The rate of PFES applied to organizations, individuals involving in ecotourism business, recreation, leisure is minimally equal to $1 \%$ of the total revenue gained in the term". Besides, Article 4 of Law on forestry (2017) also allows accounting of PFES as part of the product cost.

During the survey, all 24 companies showed their understanding of the importance of the forest to their business. They agreed that forest has generated benefits to their businesses and so they were willing to participate in the implementation of PFES. They confirmed their agreement of any PFES rate as regulated by the Government as long as it is ensured in the manner of fairness and duplication avoiding. A study by Nguyen (2016) showed that tourists' willingness-to-pay (WTP) is the most concern of tourism companies The companies would like to know whether increasing prices of their tourist products (due to the payment for PFES) could be the cause of decreasing number of tourists or not. Moreover, they also would like to know if PFES put impacts on their business or not [23]. A study by Van Hieu et al. (2019) also suggested that $1 \%$ of revenue for PFES is the appropriate rate for tourism [28].

The representatives of the travel agencies agreed with PFES collection measures by increasing entrance ticket price and room price in tourist attractions. The ticket and room prices are usually included in the tour package, therefore, the application of PFES will be a legal basis for the agencies to increase their tour price by increasing the prices of rooms and entrance tickets. 
However, the PFES application should be informed 3 to 6 months in advance so that the companies could set up their finance structure and suitable business plans.

Regarding the tourist ticket and accommodation, the survey showed that all companies agreed with the rate of $1 \%$ of revenue from ticket sales and room price. According to them, this rate is at a reasonable level. Also, they proposed that if the PFES policy is amended or changed, the travel companies should be notified at least one year before the implementation to adjust their operations. The reasons for long term preparation as followed: firstly, the ticket prices at some tourist attractions are stipulated by the province People's Committee (such as entrance tickets in Ham Rong tourist attractions). Therefore, the changes in the ticket price to adapt to the new PFES must follow the regulation procedure and take time to revoke the old tickets and issue the new ones. Secondly, many tours are usually booked in advance from 6 months to 1 year, therefore, it would be too urgent for companies to adjust their operations if they are not informed new PFES policy soon.

\subsection{Tourism - PFES recipients}

As regulated by law, PFES-recipients include forest owners; organizations, households, individuals, and communities who have forest protection and development contracts with state-own forest owners; commune people's committees and other organizations who are assigned to manage forests by the local government (Article 63, Forestry Law 2017).

The survey results revealed that $65 \%$ of interviewed companies agreed that money collection from PFES in tourism should be equally invested for both forest owners and afforestation projects (see Figure 6). About 15\% of the companies said that forest owners should be paid while $20 \%$ of the companies would like to give priority to the projects. This result showed that tourist ticket companies and accommodation service companies paid for PFES concerned much about forest owners and hoped that the money should be transferred to the forest owners who directly protect the forests. As the up-land households in Lao Cai province are among the poorest and most vulnerable to climate change [29], this PFES payment could also help improve the local livelihood. Accordingly, most of the interviewed companies hope that PFES will be paid to forest owners or projects in Sa Pa town only, and should not be shared with the other localities in Lao Cai Province.

Besides, some companies emphasized that the payment in cash to the forest owners who are ethnic minorities should be checked carefully and monitored strictly instead of relying on the contract terms. Because, many ethnic residents do not know money management, therefore, a big amount of money from the PFES might cause some problems while the effectiveness of forest protection is not enhanced. Therefore, the Lao Cai Forest Protection and Development Fund should consider in their stipulating investment principle for local landscape areas. If we cannot determine the forest areas where provide the landscape services, the PFES should be paid basing on administrative boundaries. The PFES collection amount of the district shall be used to pay for forest owners in that district.

The survey also revealed that most forest owners hope to receive PFES in tourism to protect forests better. Forest Management Board shared that the current investment for afforestation of 3 million VND per ha per year is not sufficient for landscape afforestation in Sa Pa effectively, while many bare areas have not been covered. An option to refer to is that only local landscape areas will be paid, for example, the amount of money of PFES of a district can be used to pay for forest owners in that district. In fact, unlike the forest areas providing services for hydropower or clean water production, which can be clearly defined, the areas reserved for services of landscape and recreation purposes might be difficult to clarify. It is suggested that in the case cannot identify the forest owners, the PFES resource may be used for investment in forest development in the area, according to the approval of the province People's Committee. 


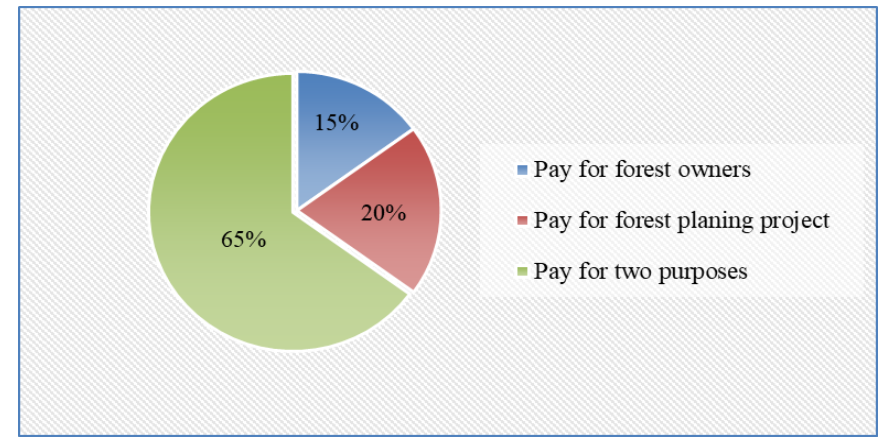

Figure 6

Opinions of tourism companies about the use of money paid for PFES

Besides, the basis for payment is based on the contracts with local individuals/ households for forest protection with a priority to poor ethnic minorities (Decree 135/2005/ND-CP). For example in Ba Vi National Park, To et al. study in 2012 shows that forest protection based on contracts is not always fair [30]. Households who could access the program earlier, are often households whose family members are local government officials. They often receive more convenient forest areas. Immigrated households, especially recent migrants, are less likely to have access to land, thus being excluded from the PFES policy, although their livelihoods highly depend on the forests. The application of PFES payments based on past forest allocation contracts will also exacerbate existing inequalities since these contracts have been implemented for decades.

Moreover, the cash payment to ethnic minority forest owners should be under good care and strict monitoring rather than the contract terms. The reason is that many ethnic households do not aware of money management, therefore, when receiving a payment amount from PFES without the instruction of how to use money effectively, it may cause some social evils while forests might not be protected.

At the same time, publicity and transparency in PFES collection amount management should be taken into consideration. The payments derived from PFES and expenditures need to be independently audited to ensure transparency. Besides, the Forest Protection and Development Fund may consider publicly disclosing payment information on the Website's Fund to enhance the transparency in PFES.

\section{Conclusion}

In Vietnam, PES has been applied in the forestry sector, known as payment forest environmental services (PFES). To ensure the nature of PFES in tourism and the right benefits from the forests as well as to avoid the overlap in PFES application, the following tourism businesses should be applied including accommodation service providers benefiting from forest ecosystem services (base on revenue from room rate) and entrance ticket sale at forest-based tourist sites (base on revenue from ticket sale).

In terms of the PFES payment level, 1 percent of revenue from ticket sales and room charge is a reasonable level. This rate receives a high consensus from stakeholders. However, a suggestion of PFES implementation from payers that they should be informed before PFES comes into effect from 3 to 6 months in advance. Moreover, the amount of PFES collection must be used effectively which must be allocated for the right purposes such as forest protection, maintaining the value of the landscape to serve tourism. Likewise, to ensure fairness and transparency in PFES, the strictly relevant monitoring measures should be considered to apply for forest owner payment rather than the contract terms. Additionally, a periodic reporting mechanism should be developed to underpin the nature of PFES. 


\section{References}

[1] Wunder S, Engel S \& Pagiola S. (2008). Taking stock: A comparative analysis of payments for environmental services programs in developed and developing countries. Ecological Economics, 65(4), 834-852.

[2] Grima N, Singh S J, Smetschka B \& Ringhofer L. (2016). Payment for Ecosystem Services (PES) in Latin America: Analysing the performance of 40 case studies. Ecosystem Services, 17, 24-32.

[3] Salzman J, Bennett G, Carroll N, Goldstein A \& Jenkins M. (2018). The global status and trends of payments for ecosystem services. Nature Sustainability, 1(3), 136-144.

[4] Landell-Mills N \& Porras I T (2002). Silver bullet or fools' gold?: a global review of markets for forest environmental services and their impact on the poor. Instruments for sustainable private sector forestry series. International Institute for Environment and Development, London.

5] Arriagada R \& Perrings C. (2013). Making payments for ecosystem services work. In Values, Payments, and Institutions for Ecosystem Management (pp. 16-57): Edward Elgar Publishing.

[6] Ezzine-de-Blas D, Wunder S, Ruiz-Pérez M \& del Pilar Moreno-Sanchez R. (2016). Global patterns in the implementation of payments for environmental services. PloS one, 11(3), e0149847.

[7] Pagiola S. (2008). Payments for environmental services in Costa Rica. Ecological Economics, 65(4), 712-724.

[8] Pagiola S, Agostini P, Gobbi J, De Haan C, Ibrahim M, Murgueitio E, Ramírez E, Rosales M \& Ruíz, J P. (2004). Paying for Biodiversity Conservation Services in Agricultural Landscapes. Environment Department Paper No. 96. Proceedings of the Murgueitio E., Ramírez E., Rosales M., Ruíz JP

[9] Prokofieva I. (2016). Payments for ecosystem services-The case of forests. Current Forestry Reports, 2(2), 130-142.

[10] Wunder S \& Albán M (2008). Decentralized payments for environmental services: The cases of Pimampiro and PROFAFOR in Ecuador. Ecological Economics, 65(4), 685-698.

[11] Perrot-Maitre D. (2006). The Vittel payments for ecosystem services: a "perfect" PES case. International Institute for Environment and Development, London, UK, 24.

[12] Nelson F. (2008). Developing Alternative Frameworks for Community-based Conservation: Piloting Payments for Environmental Services (PES) in Tanzania's Simanjiro Plains. Report prepared for WCS TransLinks Program. Tanzania: USAID.

[13] Bennett M T. (2008). China's sloping land conversion program: Institutional innovation or business as usual? Ecological Economics, 65(4), 699-711.

[14] Claassen R, Cattaneo A \& Johansson R. (2008). Cost-effective design of agri-environmental payment programs: US experience in theory and practice. Ecological Economics, 65(4), 737-752.

[15] Muñoz-Piña C, Guevara A, Torres J M \& Braña J (2008). Paying for the hydrological services of Mexico's forests: Analysis, negotiations, and results. Ecological Economics, 65(4), 725-736.

[16] Yin S \& Vang S. (2019). Payment for Ecosystem Services in Cambodia: Challenges and Potential. In Stewart M., Coclanis P. (eds) Water and Power. Advances in Global Change Research (Vol. 64): Springer, Cham.

[17] Milne S \& Chervier C. (2014). A Review of payments for environmental services (PES) experiences in Cambodia (Vol. 154): CIFOR

[18] Clements T, John A, Nielsen K, An D, Tan S \& Milner-Gulland, E. (2010). Payments for biodiversity conservation in the context of weak institutions: Comparison of three programs from Cambodia. Ecological Economics, 69(6), 1283-1291.

[19] Solgaard A, Rucevska I, Neumann C, Cavaliere C, Lutz S, Fernagut M \& Julseth M. (2012). Vital Graphics on Payment for Ecosystem Services: Realising Nature's Value. GRID-Arendal, Norway.

[20] Capodaglio A G \& Callegari A J R. (2018). Can Payment for Ecosystem Services Schemes Be an Alternative Solution to Achieve Sustainable Environmental Development? A Critical Comparison of Implementation between Europe and China. 7(3), 40.

[21] Pham T T, Bennett K, Vu T P, Brunner J, Le Ngoc D \& Nguyen D T. (2013). Payments for forest environmental services in Vietnam: from policy to practice. CIFOR Occasional Paper, (93).

[22] Nguyen H V \& Nguyen N H. (2018). Estimation of Recreation Value and Payment for Forest Environmental Services: An Application of Travel Cost Method in Vietnam. Journal of Asian Review of Public Affairs and Policy, 3(2).

[23] Nguyen N H. (2016). Study report: Economic valuation of ecosystem services to develop payment for forest environmental services mechanism on tourism in Lao Cai province. In Y. Hiromi (Ed.), Economic valuation of ecosystem services to develop payment for forest environmental services mechanism on industrial production and tourism in Lao Cai and Thua Thien Hue province (pp. 43110). Hanoi: ADB/TA-8592: iPFES. 
[24] People's Committee of Sa Pa district. (2018). Report on results of the implementation of socioeconomic development tasks in 2018; Socio-economic development plan for 2019.

[25] FAO. (2003). Tropical forest valuation: has it all been a futile exercise. Proceedings of the Paper submitted to the XII World Forestry Congress. Retrieved from: http://www.fao.org/docrep/article/wfc/xii/ms3-e.htm

[26] De Groot K. (2011). Payments for environmental services (PES) from tourism. A realistic incentive to improve local livelihoods and sustain forest landscapes in Viet Nam's northern highlands [MSc thesis]. Bogor, Indonesia.

[27] Wunder S. (2015). Revisiting the concept of payments for environmental services. Ecological Economics, 117, 234-243.

[28] Van Hieu, N, Nam N H, Van Trung P \& Tuan T M (2019). Estimation of Tourists' Willingness to Pay in $\mathrm{Ba}$ Vi National Park: Choice Experiment Method. VNU Journal of Science: Policy and Management Studies, 35(4)

[29] Hidalgo H, Nam N H \& Phuong N T B. (2020). Livelihoods of Mountainous Sites in Vietnam and Philippines: are they Threatened From Cold Spell and Typhoon? International Journal on Advanced Science, Engineering and Information Technology, 10(1), 331-343. DOI:10.18517/ijaseit.10.1.10701

[30] To P X, Dressler W H, Mahanty S, Pham T T \& Zingerli C. (2012). The prospects for payment for ecosystem services (PES) in Vietnam: a look at three payment schemes. Human ecology, 40(2), 237249. 